\title{
Biology in China suffers from government neglect
}

\begin{abstract}
Beijing. The life sciences in China are being left out in the cold, say a group of prominent researchers who have asked the government to create a national biomedical research fund. As evidence, the scientists point to a growing gap between China and the rest of the world in such fields as molecular biology, genetics and immunology as well as a recent decision by the State Education Commission to eliminate biology from the national college entrance examinations.

"The progress and development of biomedical science has direct implications for controlling population growth, improving living standards, and mitigating the effects of ageing and disease", according to a recent letter to the State Science and Technology Commission and to the Ministry of Public Health signed by 10 well-known biomedical scientists. "All developed countries have placed biomedical sciences in strategic po-
\end{abstract}

sitions and have set up a special fund to provide long-term consistent support."

The scientists, including Wu Jie-Ping, a member of the Chinese Academy of Sciences, lament the size of the Chinese biomedical community and its output relative to other countries, including those in the developing world. A recent analysis by the Institute for Scientific Information in Philadelphia, for example, found that the relative impact of Chinese papers in molecular biology, genetics, cell biology and immunology has fallen substantially in the past five years, whereas research in metallurgy, computer sciences, nuclear engineering and instrumentation has become more visible.

The government's attitude is reflected in its decision last year to exclude biology from the university entrance examinations. The proposal was part of a reform plan submitted by the Beijing municipal educa-

\section{Canadian drug companies fund universities}

Quebec. Canada's leading pharmaceutical companies have increased their support for a government-run partnership as part of a promise to spend C\$200 million (US\$160 million) over the next five years on university-based research. The money will be distributed by the Medical Research Council (MRC), the chief federal source of biomedical research funding.

The action by the Pharmaceutical Manufacturers Association of Canada (PMAC) comes at a time when the Canadian government has told researchers to look to the private sector or to their provincial governments for additional funding. It is consistent with the MRC's new strategic plan, which places great emphasis on such partnerships (see Nature 361, 102; 1993). And it follows on federal legislation enacted last year that extends drug patent protection in return for greater research spending by industry (see Nature 355, 666; 1992).

The partnership enlarges a programme begun in 1986 in which industry provides two dollars for each dollar spent by the MRC. The grants are for industry-related research at universities as well as for fellowships and visiting chairs to attract experienced industrial scientists to campus. The government intends to increase its annual contribution to the programme from $\mathrm{C} \$ 7$ million to C $\$ 10$ million, thereby raising industry's share to C\$20 million a year.

The money will also set up a two-way, national electronic database to provide industry with greater access to those in the MRC's peer-review system and to other academic scientists. The current systems are university-based, limited in scope and not accessible by industry. "It's a little ponderous and it takes a long time to work through", says Gordon Postlewaite of the PMAC. "The whole programme is being restructured by MRC to be much more responsive."

Using the new system, a company will be able to identify experts in a particular field; in return, universities can increase their contacts with industry. The database provides industry with what Postlewaite calls "the Good Housekeeping stamp of approval the high quality of MRC peer review - and a very efficient turnaround time". The partnership will pay start-up costs for the database, which will later be financed with user fees.

The partnership gives industry a chance to train researchers in specialized niches with potential labour shortages, while providing university researchers with additional funding. Intellectual property rights to inventions arising from such joint activities will be settled through negotiations.

Although Postlewaite admits that some researchers may be concerned about accepting money from industry, he says that there is no attempt to hide the funding source and that, in any event, such reservations are no longer valid. "A few people in basic research still have this expectation that industry somehow owes them money to spend as they see fit, without any accountability or relevance to the marketplace's need for a return on investment", he says. "But with money as scarce as it is, I think that most universities have decided to face reality."

David Spurgeon tion authorities to the state commission, which quickly accepted it. The changes, which take effect this year, have been adopted by 10 other provinces.

There are two versions of the current tests, one for science majors and one for social science students. While everyone must be tested on Chinese language, mathematics, politics and English, the science examination also includes physics, chemistry and biology and the social sciences covers history and geography.

The official reason for the change, which also drops geography from the list of subjects to be covered, is the desire to reduce the work-load on high school students, who compete intensely for the chance to be among the 3 per cent of the population admitted to institutions of higher education. But biologists and geographers believe that the strain on students should be relieved by improved teaching methods and better textbooks, not by narrowing the scope of their education. They also fear that high schools will start to drop the two subjects from their curricula if students do not need them for university admission.

Biologists are also worried that introductory courses will have to be simplified if students have not taken the subject beforehand and that, as a result, students will learn less biology during their undergraduate years. As an alternative, the researchers have suggested combining physics, chemistry and biology into a single test.

You Qin Li

\section{Storm damages largest US station in Antarctica}

Washington. A two-day storm last week with sustained winds of more than 100 knots damaged several buildings at McMurdo Station, the hub for US activities in Antarctica.

The punishing storm ripped off the roof of a building containing high-frequency radio transmission equipment and embedded a sheet of plywood from a storage shed into the wall of another building several hundreds yards away. No serious injuries were reported among the 236 people wintering over at the base, which has a summer population of about 1,200 .

Officials trying to assess the damage are hindered by snow drifts as high as 12 feet produced by snow that blew horizontally for 48 hours. David Bresnahan, station manager, says that the repairs will take several months and that construction crews will have to be diverted from other scheduled activities, including the completion of the new science building. The loss of the highfrequency radio equipment, he adds, is likely to hinder communications next season with scientists at field stations in the interior of the continent. 